\title{
FOOD INTOLERANCE AND CUSTOMER BEHAVIOR SPECIFICS AS A LIMITING FACTOR FOR TRAVELLING
}

\author{
Daniela ŠÁLKOVÁa , Lucie TICHÁ \\ ${ }^{a}$ Department of Trade and Finance, Faculty of Economics and Management, Czech University of Life \\ Sciences, Prague, Kamýcká 129, 16500 Prague, Czech Republic, salkova@pef.czu.cz \\ b Department of Trade and Tourism, Faculty of Economics, University of South Bohemia in České \\ Budějovice, Studentská 13, 37005 České Budějovice, Czech Republic.
}

Cite this article: Šálková, D., Tichá, L. (2020). Food Intolerance and Customer Behavior Specifics as a Limiting Factor for Travelling. Deturope. 12(1), 119-135.

\begin{abstract}
Background: A wide range of food allergies is now more or less commonplace in many people. The number of people with these food restrictions has increased several over recent decades. When making purchases, these consumers ask and require non-standard and specific types of food. There are some limitations and risks associated with eating food while travelling. The specific food allergy, in this case, is gluten intolerance, which is used to show the behaviour of consumers in restaurants. Aim: The study aimed to identify the factors influencing the purchases of gluten-free foods, and to propose ways to tailor services in restaurants to the target group of consumers. There is a gap in the research in this area, and consumer behaviour and their preferences in public food establishments have not been determined. Method: Consumer behaviour by people with gluten intolerance and the availability of food following the principles of a gluten-free diet in the foodservice sector was studied using comprehensive comparative research combined with quantitative and qualitative research using individual interviews. The data was collected from October 2016 until June 2017. A total of 1,611 patients with coeliac disease were addressed. The availability of gluten-free meals (the availability of dining) in the public food service network was examined through a field survey from February to April 2017 in three types of foodservice units. A total of 370 food operations were visited. Results: The survey revealed very urgent demand from consumers (those suffering coeliac disease) to expand the range of meals in the foodservice units. In spite of the growing number of consumers who need a gluten-free diet, this situation is not sufficiently addressed by most restaurants.
\end{abstract}

Keywords: consumer, food, behaviour, food allergy, hospitality, travelling, coeliac disease, gluten-free

\section{INTRODUCTION}

Data on the incidence of food allergies and intolerances indicate that $12-20 \%$ of people across the world believe they are allergic or intolerant to a food ingredient (Hlavatá, 2016).

Travelling people with food intolerance brings many specific problems and requirements.

Food allergy limits millions of potential travellers from participating in regular travel and tourism activities. The results of the study (Dano et al., 2015) show that food allergies prevent $14 \%$ of respondents from travelling, $49 \%$ are anxious, and $46 \%$ fear food allergies. $67 \%$ of passengers expressed difficulties in food intake in restaurants. The diet must consist of suitable products, and it is often difficult to secure and store them while travelling. Coeliacs have been 
found significantly restricted in several specific areas of life, such as physical health, social, psychological and catering, i.e., the need for gluten-free food, catering and travelling (Lee \& Newman 2003; Sverker et al., 2005; Sverker et al. 2009; Ilkóová, 2008). Food plays a central role in tourism (Schiefert \& Matteucci, 2018). Food is the subject of various types of tourism products and is a common theme in marketing by businesses and destination authorities (Henderson, 2009). There are even tourists who take experience with food consumption as a primary objective of travelling. This phenomenon is also called "culinary tourism" (Long, 1998).

\section{THEORETICAL BACKGROUND}

Celiac disease, which affects a variety of aspects of life, is one of the major intolerances that occur. The work is, therefore, focused on coeliac disease. Coeliac disease is an autoimmune genetic disorder. This means that after gluten is consumed, the body has an immune reaction that damages the body itself. Although attempts are being made to find appropriate medication, there is currently no adequate drug for coeliac disease. The only option is to avoid eating gluten, which is the trigger for undesirable body reactions. This can only be achieved by a lifelong adherence to a gluten-free diet.

On the one hand, faithful compliance with this diet improves the quality of life, as physical difficulties usually disappear very quickly. On the other hand, the patient's diet is limited in many ways. Eating in restaurants is one of these limitations, as it still presents a problem for coeliac sufferers. The lack of interest in coeliac sufferers in restaurants is probably still due to the low awareness of this disease and the failure to see the potential in addressing this group of consumers. However, restaurants could use the creation of a menu for coeliac sufferers as a way to expand their consumer base. Approximately 10,000 people who have been diagnosed with coeliac disease live in the Czech Republic. Estimates suggest that the real number is closer to 100,000-150,000. Due to advances in medical knowledge in this area, the number of diagnosed individuals continues to increase. At the same time, there are not many restaurants that can offer their consumers dishes that meet the principles of a gluten-free diet.

Coeliac disease, also known as coeliac sprue or gluten enteropathy, is an autoimmune disorder. The disease has many clinical manifestations, from severe malabsorption to minimally symptomatic or non-symptomatic presentation (Lebwohl, Sanders, \& Green, 2018). In these patients, the ingestion of gluten proteins from cereals such as wheat, barley, and rye causes damage to the mucus lining of the small intestine, with potentially serious consequences (Reale et al., 2017). The resulting antibodies then damage the mucus lining of the small intestine 
(Kohout \& Pavlíčková, 2010). The mucus lining is gradually smoothed, preventing the intestine from properly absorbing protein, fat, vitamins, and other important nutrients (Červenková, 2006). In this situation, the body is incapable of functioning correctly. A whole range of unpleasant symptoms including stomach pain, diarrhoea or constipation appear (Kohout \& Pavlíčková, 2006),

Coeliac disease is a life-long illness. Currently, there is no permanent cure. However, it can be quite successfully suppressed by life-long adherence to a gluten-free diet. Most patients with coeliac disease are predominantly satisfied once they go on a gluten-free diet (Faye et al., 2018). Nevertheless, a life-long gluten-free diet can still be a major limitation in the normal life of many patients. Estimates of coeliac disease are based on the long-term study of patients and their relatives, the incidence of associated, especially autoimmune diseases, and, recently, even screening studies (Hes, 2014). Gender differences are minimal in the case of coeliac disease (Jansson-Knodell et al., 2018). The greatest damage to the mucus lining of the intestines is caused by wheat or the gliadin it contains, followed by rye (secalin), barley (hordein) and, the least toxic, the avenin in oats (Tessmer, 2003).

Coeliac is a disease that interferes with many aspects of life and brings many constraints. Gluten-free dieting entails lifestyle changes (Moore, 2017), especially eating and travelling (Lee \& Newman, 2003) and the social dimension of life (de Lorenzo et al., 2012). In addition to the need to carefully study food labels, a gluten-free diet has other pitfalls. These include, for example, the availability and diversity of the gluten-free product range, which is still very limited despite the rapidly growing nature of the market (Gao, Marlene, \& Chaiya, 2017). Another disadvantage is the high price of gluten-free products. Although the line of gluten-free products has improved, their price remains high (Jamieson \& Gougeon, 2017). A gluten-free diet is, therefore, always associated with higher costs (Fry, Madden, \& Fallaize, 2018). The survey of gluten-free products on the Czech and Slovak markets shows that the price of these foods is two- to eight-times higher (Regnerová \& Hes, 2013). This finding is confirmed by other studies showing that the price of gluten-free products is in the order of tens to hundreds of percent higher compared to their conventional equivalents (Panagiotou \& Kontogianni, 2017).

A gluten-free diet can complicate eating away from home. The quality of the provided food is of key importance in the case of coeliac disease (Leiss, 2017). Besides that, the offer of gluten-free dishes is often quite limited, a factor particularly problematic in school and factory canteens, which can pose a significant limitation in the everyday life of coeliac patients 
compared to healthy individuals (Frič \& Mengerová, 2008). Children suffering from this disease can face social exclusion as a result of their different dietary needs (Olsson et al., 2008). The insufficient level of gluten-free alternatives in restaurants is still evident despite efforts to offer healthier food options (Jun, Kang, \& Arendt, 2014). The influence of healthy food on the restaurant business remains somewhat underappreciated (Kim et al., 2013). Food preparation is also crucial for a gluten-free diet. Simply omitting contaminated ingredients during cooking is not sufficient. The kitchen staff should at least be trained at a basic level, which is also confirmed by the research of Towers and Pratten (2003) - in connection with food allergies, those involved in the preparation and serving of food must be provided with more information. Yet, despite these limitations, restaurants represent an important place in terms of social contact (Thomas, Ghiselli, \& Almanza, 2011), and coeliac patients should not be forced to omit them from their lives. Understanding dilemmas, which individuals with a food intolerance face when travelling can provide tourist destinations with the necessary information so they may design their products to meet the needs of this ever-increasing market (Derham, Frost, \& Melsen, 2012).

Food allergy knowledge, attitudes, and practice have already been studied. Generally, most restaurants could easily meet food-allergic customers' special requests (Radke et al., 2016). Unmeed (2012) delt with guidelines for travelers, to get them ready and help them prevent the contact with food they are allergic or sensitive to. On the other hand, Radke et al. (2016) found out the restaurant staff members are sometimes not able to recognize specific ingredients as an allergen. According to these authors, managers, and staff sometimes believe that someone with a food allergy can safely consume a small amount of that allergen.

A positive attitude to the food intolerant guests is an important part of services quality perception. Good perception of services quality of a restaurant is an important factor of perception of an accommodation establishment (Švec, Navrátil, Pícha, and White Baravalle Gilliam, 2012, Bihamta, Jayashree, Rezaei, Okumus, \& Rahimi, 2017), a hotel resort (Murgado, 2013) or a tourist destination (Popovic, Delibasic, \& Ognjanovic, 2018).

\section{DATA AND METHODS}

The consumer preferences of persons with gluten intolerance and offers of dishes complying with the principles of a gluten-free diet public food establishments (mapping the preferences of a specific group of consumers with a gluten-free diet in connection with the examination of 
selected factors that are the main determinants of their demand and decision-making when purchasing food services), including the impact of coeliac disease on the life of patients, were determined to employ comprehensive comparative study with a combination of quantitative and qualitative research using individual interviews.

\section{Data collection}

Consumer preferences were explored using quantitative research methods. Individuals included in the study had to meet two criteria: they had to be 15 years of age or older and diagnosed with coeliac disease. People who adhere to a gluten-free diet voluntarily were not included in the study, as the needs of coeliac patients differ from those who choose not to eat gluten on their own. As there is not a database of coeliac patients in the Czech Republic, the respondents were addressed with the help of coeliac associations or organizations. Even a base of e-mail addresses was available, or the collaborative entities placed the link to the electronic questionnaire within their web pages. The age was chosen to allow the respondent to decide on participation on their own (not their parents) and to ensure that they have some experience eating in public food service facilities. The data was collected from October 2016 until June 2017. A total of 1,611 patients with coeliac disease were addressed; 48 individuals had to be excluded because their surveys were incomplete or inaccurate (Tab. 1).

Table 1 The sociodemographic characteristics of respondents

\begin{tabular}{|c|c|c|c|}
\hline Variable & category & $\begin{array}{l}\text { absolute } \\
\text { (number } \\
\text { persons) }\end{array}$ & relative $(\%)$ \\
\hline \multirow[b]{2}{*}{ gender } & female & 1,113 & 71.21 \\
\hline & male & 450 & 28.79 \\
\hline \multirow[b]{4}{*}{ age } & under 20 years & 261 & 16.70 \\
\hline & $20-40$ years & 985 & 63.02 \\
\hline & $41-60$ years & 267 & 17.08 \\
\hline & $61-80$ years & 50 & 3.20 \\
\hline \multirow{4}{*}{$\begin{array}{l}\text { highest education level } \\
\text { completed }\end{array}$} & $\begin{array}{l}\text { elementary } \\
\text { school }\end{array}$ & 161 & 10.30 \\
\hline & secondary school & 833 & 53.29 \\
\hline & $\begin{array}{l}\begin{array}{l}\text { higher vocational } \\
\text { school }\end{array} \\
\end{array}$ & 24 & 1.54 \\
\hline & university & 545 & 34.87 \\
\hline \multirow[b]{4}{*}{ economic standing } & I'm studying & 582 & 37.24 \\
\hline & I'm working & 871 & 55.73 \\
\hline & retired & 62 & 3.97 \\
\hline & other & 48 & 3.07 \\
\hline
\end{tabular}


Three research questions were established for the study:

Is the current level of gluten-free dishes in restaurants sufficient in terms of the breadth and depth of the assortment?

What are the possibilities for coeliac patients when eating away from home?

How do coeliac sufferers behave when eating in restaurants, and what are their preferences?

Part of the survey was conducted in electronic form using the CAWI method (Computer Assisted Web Interviewing) mode, while some respondents were surveyed personally. The electronic questionnaires were created using the Google Docs application. Subsequently, sixteen representatives operating websites with a coeliac theme were asked to place a link of the survey on their website. The places were mostly the websites of clubs and associations of coeliac patients for different regions and websites that deal with the issue either from a medical or culinary point of view. Of the sixteen representatives addressed, seven participated in the survey. The printed questionnaires were placed in several selected restaurants, where they were presented to consumers with coeliac disease.

The availability of gluten-free dishes (the availability of dining) in the public food service network was examined by means of qualitative research/structured interviews - using a field survey from February to April 2017 in three types of foodservice units defined as:

- $\quad$ fast food establishments,

- $\quad$ restaurants with the wait staff,

- $\quad$ closed (semi-closed) forms of public food service (school canteen, company canteen, etc.).

The essence of the survey was the assessment of the situation on the Czech market, the dining possibilities, and food availability for consumers with a gluten-free diet in foodservice units in the Czech Republic.

Restaurants were visited in 77 settlements of urban, rural and non-residential parts. We have used convenience sampling to choose the settlements - according to the radius of actions of interviewers. The availability of meals for people on gluten-free diets was determined through individual interviews in 370 establishments. A random selection of restaurants within the 77 settlements created a sample of restaurants to determine the availability of dishes suitable for a gluten-free diet. The availability of food for individuals with a gluten-free diet was determined through inspections of menu contents (including information on potential allergens) and interviews with employees. Of the total of 370 facilities, 89 fast food establishments $(24 \%)$, 207 restaurants (56\%), and 74 closed dining facilities (20\%) were visited (Tab. 2). 
Table 2 Structure of foodservice facilities

\begin{tabular}{lll}
\hline type of food service facility & absolute number & $(\%)$ \\
\hline fast food establishment & 89 & 24 \\
restaurants with wait staff & 207 & 56 \\
closed forms of dining & 74 & 20 \\
\hline
\end{tabular}

\section{Data analysis}

The relationship between the obtained data was tested using a test of the correlation of qualitative characteristics in association and contingency tables. For testing correlation, two hypotheses, null H0, and alternative H1 were always established. The zero hypothesis is based on the assumption that there is no link between the variables, while the alternative hypothesis assumes the opposite. The data were then arranged in association or contingency tables, depending on the number of variations of the examined characteristics. A chi-squared test was used to calculate all correlations.

The equation for the calculation of the chi-squared test in the association table:

$\chi^{2}=\frac{\mathrm{n}(\mathrm{ad}-\mathrm{bc})^{2}}{(\mathrm{a}+\mathrm{b})(\mathrm{a}+\mathrm{c})(\mathrm{b}+\mathrm{d})(\mathrm{c}+\mathrm{d})}$

(Hindl, Hronová \& Seger, 2007)

The equation for the calculation of the chi-squared test in the

contingency table:

$\chi^{2}=\Sigma \Sigma \frac{\left(\mathrm{n}_{\mathrm{ij}}-\mathrm{n}_{\mathrm{oj}}\right)^{2}}{\mathrm{n}_{\mathrm{oj}}} \quad$ (Pecáková, 2008)

The resulting chi-squared value of the test was compared to the critical value obtained from the statistical tables., a significance level of $\alpha=0.05$ was used to determine the critical value. This means that the correlation is demonstrated with a $95 \%$ probability. The null hypothesis is rejected, and the alternative hypothesis accepted when the calculated test value is greater to the critical value. In this case, the strength of the correlation is also determined. In the case of the association table, the calculation of the association coefficient $\mathrm{V}$ is used, while in the case of the contingency table, the Pearson contingency coefficient $\mathrm{C}$ is used.

Coefficient of association:

$$
v=\frac{a d-b c}{\sqrt{(a+b)(a+c)(b+d)(c+d)}} \quad \text { (Řezanková, 2007) }
$$

Pearson's contingency coefficient: 
$\mathrm{c}=\sqrt{\frac{\mathrm{x}^{2}}{\mathrm{x}^{2}+\mathrm{n}}} \quad$ (̌̌ezanková, 2007)

The result of the calculations is a number with values in the interval $<0 ; 1>$, which is interpreted in written form. In order to accurately interpret the dependency that was found in the contingency tables, the sign diagram of deviations is applied.

The SAS 9.4 statistical programme was used for the statistical processing of correlations of qualitative characteristics.

Answers from the structured questionnaires were aggregated and analysed be means of thematic analysis.

\section{RESULTS}

\section{Preferences of people with gluten-free diets when dining out}

Eating away from home may pose a considerable health risk for coeliac sufferers. A common problem with out-of-home food services in the case of coeliac disease is the limited choice of suitable meals. The most common reasons, why people with coeliac disease do not visit restaurants or, other food establishments are as follows: mistrust; financial difficulty; limited assortment; a small variation in offered dishes; the lack of gluten-free restaurants; the unwillingness of staff; fear of cross-contamination; non-compliance with hygiene principles; uneducated staff; unsuitable meals for coeliac patients; insufficient information on ingredients and a high degree of health risk. A major shortcoming in public food service in the case of coeliac disease is the very narrow range of offered meals. Mostly, all types of foodservice establishments (except for specialised restaurants) offer coeliac patients only naturally glutenfree foods. The vast majority of coeliac patients $(80.25 \%)$ consider the range of gluten-free dishes offered in restaurants to be inadequate. For this reason, most coeliac sufferers $(90.85 \%)$ would welcome an increase in the supply of gluten-free meals in restaurants and other types of hospitality establishments with respect to better accessibility near their homes. Coeliac patients prefer specialised restaurants both with wait staff and self-service restaurants.

The majority of coeliac patients only rarely eat out during their lifetime. Only one out of four consumers reports eating in restaurants every day or every other day. The correlation between the intensity of searches for gluten-free meals in food service establishments and selected variables is shown in Tab. 3 . 
Table 3 Correlation between the intensity of searches for gluten-free meals in food service establishments and selected variables

\begin{tabular}{llllll}
\hline variable & $\chi^{2}$ & P-value & Cramer's V & correlation & $\begin{array}{l}\text { strength of } \\
\text { correlation }\end{array}$ \\
\hline gender & 5.2401 & 0.1550 & 0.1090 & no & \\
age & 27.1475 & 0.0074 & 0.1432 & yes & weak \\
education & 11.8074 & 0.2244 & 0.0945 & no & \\
\hline
\end{tabular}

A statistically significant correlation was not demonstrated in the case of the relationship between gender and frequency of eating out in foodservice establishments. The frequency of searching for places to eat is not influenced by gender. A statistically significant relationship was demonstrated between the age of consumers - coeliac patients and the frequency of eating out at foodservice establishments since the value $\mathrm{p}=0.0074$, in this case, is lower than the chosen significance level $\alpha=0.05$. In terms of the strength of the correlation, the connection is weak. This means that age and the economic activity of the given person are directly related to the intensity of use of the services of restaurant establishments. Persons aged 20-40 years, i.e., people of working age (74.61\%), clearly eat out at restaurants most frequently. Younger (under 20 years) and persons older than 60 years of age mainly eat in a different way.

We have found a statistically significant relationship between selected criteria and the frequency of eating out at a hospitality establishment. The criteria - such as the freshness and quality of food; price level; the assortment of gluten-free food; the waiting staff; opening hours -influence the willingness to go out for eating when required to keep a gluten-free diet, then. The strength of the correlation is weak. It is possible to say that the range of the menu and the freshness and quality of the offered food have a positive effect on the frequency of eating out at restaurants. In terms of restaurant establishment menus, persons with this specific diet plan very often perceive the limited menu as a major shortcoming, which also lacks variety and is almost identical in all food service establishments. The low variability of dishes on the menu is similar even in the case of closed establishments.

A visit to a particular type of food service establishment depends on various criteria. The null hypothesis assumes, in this case, that the critical factors for eating out at a food service establishment are not, e.g., freshness and quality of food, assortment, etc. The results of the conducted $\chi 2$ test show that the null hypothesis can be rejected. Thus, consumers decide on whether or not to use the services of a food establishment primarily based on the listed criteria. The strength of the correlation is relatively high when judged by the contingency coefficient. However, because this coefficient is influenced by the contingency table that has been created, it is preferable to assess the intensity of correlation using Cramer's V, which does not take into 
account the size of the evaluated table. According to this coefficient, the correlation can be evaluated as weak.

Important aspects of choosing a particular food from the available offer of the foodservice facility, according to which coeliac patients most commonly make buying decisions, are the health aspects and their impacts on the body, and previous good experience (Fig 1).

Figure 1 Perspective for choosing dishes in a food service facility (\%)

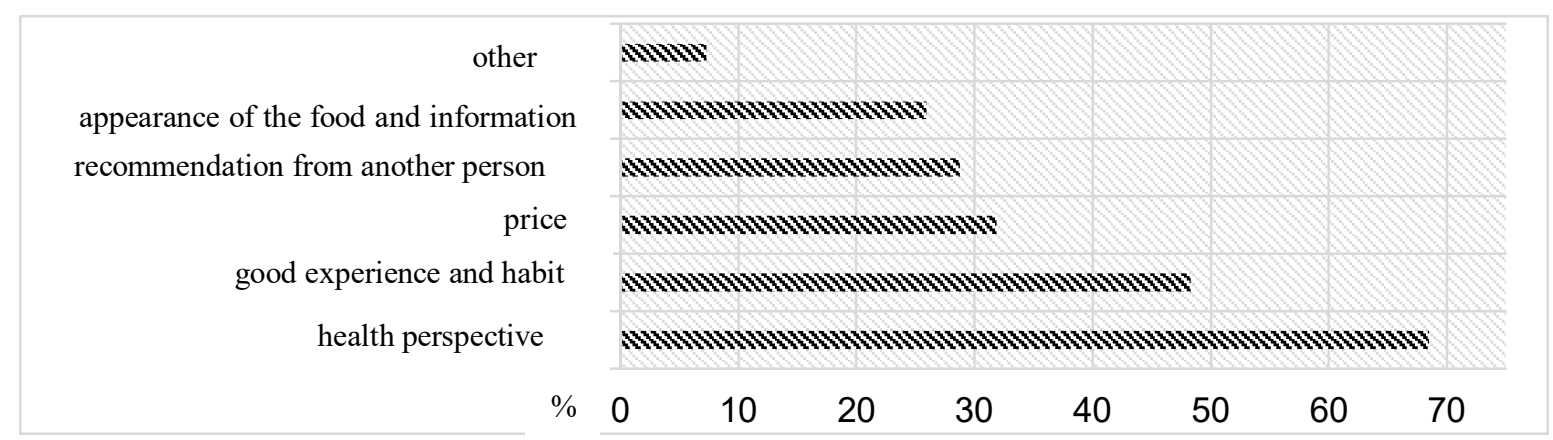

A strong correlation (Tab. 3) was statistically demonstrated in the case of monitoring the impact of selected criteria (significance for the body in the case of coeliac disease; the importance of improving the quality of life for coeliac patients; good experience and habit; recommendations from others; the appearance of gluten-free food and information from the waiting staff). Those criteria are decisive when buying specific gluten-free meals in terms of the type of food service establishment. Individuals whose purchasing decisions prioritise the health aspects of their disease, good experience with the given dining establishment, and the importance of improving the quality of life prefer the restaurant type of foodservice establishment with wait staff over other types of facilities.

Based on the $\chi^{2}$ test, individuals whose purchasing decisions prioritise the health aspects of their disease, good experience with the given dining establishment and the importance for improving the quality of life prefer the restaurant type of hospitality establishment with wait staff over other types of facilities (Table 4). The decisive factor, in this case, is the ingredients in the given dish (61.36\%), good personal experience $(57.28 \%$ ), or a recommendation from another person $(25.29 \%)$.

Table 4 Correlation between quality assessment of gluten-free food and selected variables

\begin{tabular}{llllll}
\hline variable & $\chi^{2}$ & P-value & Cramer's V & correlation & $\begin{array}{l}\text { strength of } \\
\text { correlation }\end{array}$ \\
\hline gender & 44.5404 & 0.1554 & 0.2154 & no & medium \\
age & 451.0787 & $<.0001$ & 0.3427 & yes & no \\
education & 203.6399 & 0.1093 & 0.2060 & yes & weak \\
economic & 237.7714 & 0.0025 & 0.2226 & & \\
standing & & & & & \\
\hline
\end{tabular}


The impact of discounts and special offers when buying gluten-free meals on the selection of the type of foodservice establishment for coeliac patients was confirmed by the $\chi \chi^{2}$ test $(\mathrm{p}=$ $0.0003<\alpha=0.05$ ). The strength of the correlation can be evaluated as weak (Cramer's $\mathrm{V}=$ 0.2480 ) to moderate (contingency coefficient $C=0.3947$ ). Discounts are of great importance for $21.31 \%$ of coeliac patients and are only partially important for one-fifth of them. Therefore, discounts and special offers are an important criterion in selecting a particular food service establishment for the majority of individuals in this specific group of consumers.

The clear majority of coeliac patients consider their economic costs for eating a gluten-free diet, i.e., the price of gluten-free foods in relation to the total food expenditures, to be high (79.81\%). This shows, among other things, the financial burden of this particular disease. Since excluding foods containing gluten is basically the only way to reduce sufficiently the effects of this disease, the price of gluten-free foods and ready-to-eat gluten-free meals can significantly limit the possibilities for eating out among people with coeliac disease.

\section{The availability of food for consumers with gluten intolerance in the network of public food service establishments}

A field survey was conducted to supplement information on the possibilities of eating out for coeliac sufferers in the Czech Republic. This survey mapped the availability and offer of food for consumers with gluten intolerance in three types of operating units: fast-food restaurants, full-service restaurants with the wait staff, and enclosed facilities (e.g., school and employee canteens). The availability of food for individuals with a gluten-free diet was determined through inspections of menu contents (including information on potential allergens) and interviews with employees.

No gluten-free dishes were available on the menus of fast-food establishments, and it was necessary to ask the wait staff for information and recommendations as to what food would be suitable for a gluten-free diet. The term coeliac disease and its meaning were not known in many of the visited fast food establishments. In many restaurant-type establishments with the wait staff, guests can choose at least one dish from the daily menu that is suitable for a glutenfree diet. Sometimes a combination of other dishes is available to get such a menu, or some of the offered dishes containing gluten can be prepared as gluten-free. If a restaurant with the wait staff is located in an area with low frequency or small movement of the population, usually one or two hot dishes with soup (not necessarily gluten-free) or a made-to-order dish or cold dish are offered. Those dishes are generally served with a bakery product containing gluten. 
In all surveyed establishments, where dishes are cooked and served, the staff was mostly friendly and helpful to diners/coeliac sufferers and willing to give advice and combine readymade dishes to make them suitable for people with coeliac disease.

\section{DISCUSSION}

Increasing interest in health leads to an increase in demand for products that have a positive impact on health (Puhakka, Valve, \& Sinkkonen, 2017). Although the supply of food suitable for a gluten-free diet and its availability has greatly improved (Fry et al., 2018), the offer in foodservice establishments remains inadequate. Less affordable, not enough meals at a higher price, is a problem even in the case of school meals, as confirmed (Estevez and Araya, 2016). Eating out is part of social life for people, and people who have the coeliac disease should not be forced to forego this activity because of their health restrictions. Eating meals in restaurants, therefore, has a significant social dimension. A common reason for refusing to visit restaurants is the high health risk faced by coeliac patients. This fact is very limiting for travelling of this segment of tourists. As the food intolerance is rather a growing phenomenon, we can expect an increasing importance of this segment in tourism. To satisfy their needs would be crucial.

The health aspect is an important aspect of food demand (Zoll et al., 2017). Some changes are needed to eliminate the fears of coeliac sufferers from eating out - a gluten-free diet is the main treatment strategy (Altamimi, 2017). The vast majority of coeliac patients would welcome an increase in the offer of gluten-free meals in restaurants and other types of foodservice establishments, including in their neighbourhood. Persons with this specific diet very often perceive the limited menu in restaurants as a major shortcoming; moreover, the offer also lacks variety and is almost identical in all food service establishments. The majority of coeliac patients look for information on the internet about the offered food before visiting a restaurant/food service facility. Information on gluten-free meals should, therefore, be announced in advance on their website (weekly menu) so that the consumer/coeliac patient can decide on their daily meals. Providing information is often considered an important role in consumer decision making (Bellotti \& Panzone, 2015).

Because the combination of a "normal" restaurant with a complementary offer of gluten-free meals raises a very high risk of cross-contamination with gluten (Rostami et al., 2017) and hence the risk of health complications, specialised establishments should be established instead. New foodservice facilities intended exclusively for this type of diet could be combined with an offer for other food allergies. 
In the case of public food services for gluten-intolerant consumers, operators should focus on restaurants with the wait staff, as coeliac patients prefer such restaurants. The majority of consumers prefer restaurants with the waiting staff. A statistically significant correlation between gender and the type of foodservice facility frequented most by coeliac patients for eating out was also demonstrated. We can also say that the size of the assortment, freshness and the quality of the offered foods have a positive impact on the visitation rates of restaurants. A statistically significant correlation was proven in the case of the influence of following selected criteria (freshness and quality of food, price, assortment of gluten-free dishes, service, restaurant hours) on the frequency in searching for a gluten-free diet in food service establishments).

Restaurants should focus on consumers in the 20-40 age group and tailor the restaurant's offer to their preferences. Age and the related economic activity of the person is directly linked to the intensity of use of the services of restaurant establishments. Persons aged 20-40 years, i.e., people of working age, clearly eat out at restaurants most frequently. The specific options for gluten-free meals should be appropriately presented to these consumers. Based on established correlations, it is advisable to publish information for coeliac patients predominantly in electronic form (expert websites, patient discussions).

There is a need to improve the training and education of those involved in the gluten-free diet (Zarkadas et al., 2013). It is important to educate food service staff on the basic principles of a gluten-free diet and the basic principles of avoiding gluten-protein contamination in food preparation. Dietary counselling is generally very important in the case of coeliac patients, as presented in Leiss (2017). Even in this case, education needn't be only about a gluten-free diet and could also cover other widespread food allergies. Education in the field of food safety is essential (Gkana \& Nychas, 2017). When a coeliac patient visits a restaurant, staff willingness, and providing sufficient information on the ingredients and preparation of the dish are also important.

The gluten-free diet is associated with higher costs of buying food (Castillo \& Rivas, 2008) Discounts and special offers are therefore an important criterion in selecting a food service establishment for almost three-quarters of individuals in this specific group of consumers. Restaurant consumers can be motivated to visit more frequently by special price offers, given that the survey showed a direct link between the frequency of eating out and the importance of discounts. Special price offers can attract interest among a large group of consumers while also attracting new consumers. Therefore, food service establishments should also use this tool and 
work with the price of gluten-free dishes. If consumers are satisfied with the quality of the food, they can become regular and loyal consumers.

\section{CONCLUSION}

The biggest drawback in the impact of celiac disease is the fundamental change in eating habits and the associated limitations in different areas of life. These limitations are very significantly linked to public catering and, consequently, to travelling away from home. Gluten-free foods are generally less affordable and more expensive than regular foods (Lee et al., 2007). This situation has a negative impact on the quality of life of patients with celiac disease (Estevez et al., 2016) The survey revealed very urgent demand from consumers/coeliac patients to expand the assortment of meals in foodservice establishment because often they must resign themselves to a plain piece of meat with a potato or vegetable salad. For example, they would also welcome (even at a higher price), gluten-free dumplings, pasta, pancakes, fruit dumplings, desserts, cakes, pizza, potato pancakes, breaded cauliflower, broccoli, mushrooms, soups, and traditional Czech dishes, including beer.

The results of the field survey in selected types of foodservice units showed unevenness in the offer of meals for consumers with a gluten-free diet. The situation in the Czech market from this point of view is not satisfactory. Despite the growing number of consumers who need a gluten-free diet (Gao et al., 2017), this situation is not sufficiently addressed by most restaurants. The reason may be a lack of knowledge on the issue, but also the economic situation in the foodservice industry or insufficient training of staff (in schools).

Consumers who have a problem with the consumption of foods containing gluten represent an increasingly important consumer segment for manufacturers and distributors with glutenfree food. However, an integral part of their quality of life (Meyer \& Rosenblum, 2018) is the possibility to choose gluten-free foods, and especially gluten-free meals included on the menu of restaurants. Limited opportunities for gluten-free meals appear to be a widespread public health problem (Cataldo and Montalto, 2007). Coeliac patients can motivate restaurant operators to specialise in the offer of gluten-free and dietary meals. It is necessary to proceed with society-wide responsibility towards the population group, which is still growing, by creating the same conditions for the quality food options enjoyed by others. Destination managers are to provide some guidance or training the hospitality staff as they are obviously aware not enough, and their knowledge and willingness will probably do to improve the 
situation and satisfaction of travellers and tourists with coeliac disease or any other food intolerance (food allergy).

\section{REFERENCES}

Altamimi, E. (2017). Celiac disease in South Jordan. Pediatric Gastroenterology. Hepatology \& Nutrition 20, 222-226. https://doi.org/10.5223/pghn.2017.20.4.222

Bellotti, E., \& Panzone, L. (2015 ). Media effects on sustainable food consumption. How newspaper coverage relates to supermarket expenditures. International Journal of Consumer Studies 40, 186-200. https://doi.org/10.1111/ijcs. 12242

Bihamta, H., Jayashree, S., Rezaei, S., Okumus, F., \& Rahimi, R. (2017). Dual pillars of hotel restaurant food quality satisfaction and brand loyalty. British Food Journal, 119(12), 2597-2609

Castillo, LC., \& Rivas, CC. (2008 ). Costs of a basic food basket for celiac patients in Chile. Revista Medica de Chile 136: 613-619. https://doi.org//S0034-98872008000500010

Cataldo, F., \& Montalto, G. (2007 ). Celiac disease in the developing countries: A new and challenging public health problem. World Journal of Gastroenterology, 13, 2153-2159. https://doi.org/10.3748/wjg.v13.i15.2153

Červenková, R. (2006 ). Celiakie Disease, 1st edn. Galén-Kompas, Prague, CR.

Dano, D., Michel, M., Astier, C., Couratier, P., Steenbeek, N., Sarr, P.Y., ...Kanny, G. (2015 ). Impact of food allergies on the allergic person's travel decision, trip organization and stay ALLERGY, 70, 182-183 Supplement: 101 Special Issue: SI Meeting Abstract: 403

de Lorenzo, CM., Xikota, JC., \& Wayhs MC. (2012 ). Evaluation of the quality of life of children with celiac disease and their parents: A case-control study. Quality of Life Research 21: 77-85. https://doi.org/10.1007/s11136-011-9930-7

Derham, J., Frost, W., \& Melsen, L. (2012). Travelling with food intolerances: An exploratory study. In CAUTHE 2012: The new golden age of tourism and hospitality; Book 2; Proceedings of the 22nd Annual Conference (p. 132). La Trobe University.

Estevez, V., \& Araya, M. (2016 ). Gluten-free diet and gluten-free foods. Revista Chilena de Nutricion 43, 428-433. https://doi.org/https://doi.org/10.4067/S071775182016000400014

Estevez, V., Ayala, J., \& Vespa C. (2016 ). The gluten-free basic food basket: A problem of availability, cost and nutritional composition. European Journal of Clinical Nutrition 70: 1215-1217. https://doi.org/10.1038/ejcn.2016.139

Faye, AS., Mahadev, S., \& Lebwohl, B. (2018 ). Determinants of patient satisfaction in Celiac disease care. Journal of Clinical Gastroenterology 52, 30-35. https://doi.org/10.1097/mcg.0000000000000745

Frič, P., \& Mengerová, O. (2008 ). Celiakie: Bezlepková Dieta a Rady Lékaře, 1st edn. Medica, Čestlice, CR.

Fry, L., Madden, AM., \& Fallaize, R. (2018). An investigation into the nutritional composition and cost of gluten-free versus regular food products in the UK. Journal of Human Nutrition and Dietetics 31: 108-120. https://doi.org/10.1111/jhn.12502

Gkana, NE., \& Nychas, EGJ. (2017 ). Consumer food safety perceptions and self-reported practices in Greece. International Journal of Consumer Studies 42, 27-34. https://doi.org/10.1111/ijcs.12391

Gao, Y., Marlene, EJ., \& Chaiya, B. (2017 ). Gluten-free bakery and pasta products: Prevalence and quality improvement. International Journal of Food Science \& Technology 53, 1932. https://doi.org/10.1111/ijfs.13505

Henderson, J. C. (2009). Food tourism reviewed. British food journal, 111(4), 317-326. 
Hes, A. (2014). Maloobchod s Bezlepkovými Potravinami v České a Slovenské Republice, 1st edn. Powerprint, Praha, CZ.

Hlavatá, K. (2016). Potravinové alergie a intolerance. [online]. [cit. 2018-09-06]. Dostupné z: $<$ https://www.vimcojim.cz/magazin/clanky/o-zdravi/Potravinove-alergie-aintolerance-dil-1. s10012x9882.html $>$

Hindls, R., Hronová, S, \& Seger, J. (2007). Statistika pro ekonomy, 8th ed. Prague: Professional Publishing.

Ilkóová, V. (2008). Kvalita života při onemocnění celiakií v dospělosti [online]. České Budějovice, [cit. 2012-02-01]. Jihočeská univerzita. Dostupné z: $<$ http://theses.cz/id/cyt5wf/downloadPraceContent_adipIdno_10608>.

Jamieson, JA., \& Gougeon, L. (2017). Gluten-free foods in rural maritime provinces: Limited availability, high price, and low iron content. Canadian Journal of Dietetic Practice and Research 78: 192-196. https://doi.org/10.3148/cjdpr-2017-020

Jansson-Knodell, CL., King, KS., \& Larson, JJ. (2018). Gender-based differences in a population-based cohort with Celiac disease: More alike than unalike. Digestive Diseases and Sciences 63: 184-192. https://doi.org/10.1007/s10620-017-4835-0

Jun, J., Kang, J., \& Arendt, SW. (2014). The effects of health value on healthful food selection intention at restaurants: Considering the role of attitudes toward taste and healthfulness of healthful foods. International Journal of Hospitality Management 42: 85-91. https://doi.org/https://doi.org/10.1016/j.ijhm.2014.06.002

Kim, HJ., Park, J., \& Kim, MJ. (2013). Does perceived restaurant food healthiness matter? Its influence on value, satisfaction and revisit intentions in restaurant operations in South Korea. International Journal of Hospitality Management 33: 397-405. https://doi.org/https://doi.org/10.1016/j.ijhm.2012.10.010

Kohout, P., \& Pavlíčková J. (2006). Celiakie a Bezlepková Dieta. Dieta a Rady Lékaře, 1st edn. Maxdorf, Prague, CZ.

Kohout, P., \& Pavlíčková, J. (2010). Celiakie: Víte si Rady s Bezlepkovou Dietou? Rady Lékaře, Průvodce Dietou, 1st edn. Forsapi, Prague, CZ.

Lebwohl, B., Sanders, DS., \& Green, PHR. (2018). Coeliac disease. Lancet 391: 70-81. https://doi.org/10.1016/s0140-6736(17)31796-8

Lee, A., \& Newman JM. (2003). Celiac diet: Its impact on quality of life. Journal of the American Dietetic Association 103: 1533-1535. https://doi.org/10.1016/s0002

Lee, AR., Ng, DL., \& Zivin, J. (2007). Economic burden of a gluten-free diet. Journal of Human Nutrition and Dietetics 20: 423-430. https://doi.org/10.1111/j.1365-277X.2007.00763.X

Leiss, O. (2017). Gluten-free diet - Update 2017. Zeitschrift fur Gastroenterologie 55: 13231343. https://doi.org/10.1055/s-0043-120347

Long, L. M. (1998). Culinary tourism: A folkloristic perspective on eating and otherness. Southern Folklore, 55(3)., 181.

Meyer, S., \& Rosenblum, S. (2018). Daily experiences and challenges among children and adolescents with Celiac disease: Focus group results. Journal of Pediatric $\begin{array}{lll}\text { Gastroenterology Nutrition } & \text { and }\end{array}$ https://doi.org/10.1097/mpg.0000000000001635

Moore, LR. (2017). Food intolerant family: Gender and the maintenance of children's glutenfree diets. Food, Culture \& Society 20: 463-483. https://doi.org/10.1080/15528014.2017.1288792

Murgado, E. M. (2013). Turning food into a gastronomic experience: olive oil tourism. Options Mediterranéennes, 106, 97-109.

Olsson, C., Hornell, A., \& Ivarsson, A. (2008). The everyday life of adolescent coeliacs: Issues of importance for compliance with the gluten-free diet. Journal of Human Nutrition and Dietetics 21: 359-367. https://doi.org/10.1111/j.1365-277X.2008.00867.x 
Panagiotou, S., \& Kontogianni, MD. (2017). The economic burden of gluten-free products and gluten-free diet: A cost estimation analysis in Greece. Journal of Human Nutrition and Dietetics 30: 746-752. https://doi.org/10.1111/jhn.12477

Pecáková, I. (2008). Statistika v terénních průzkumech. Prague: Professional Publishing.

Popovic, O. B., Delibasic, M., \& Ognjanovic, I. (2018). The Perception of the Tourist Services Quality with Model for Predicting the Likelihood Of Returning To The Destination. Transformations in Business \& Economics, 17(3), 206-220.

Puhakka, R., Valve, R., \& Sinkkonen, A. (2017). Older consumers' perceptions of functional foods and non-edible health-enhancing innovations. International Journal of Consumer Studies 42: 111-119. https://doi.org/10.1111/ijcs.12400

Radke, T. J., Brown, L. G., Hoover, E. R., Faw, B. V., Reimann, D., Wong, M. R., ... \& Ripley, D. (2016). Food allergy knowledge and attitudes of restaurant managers and staff: an EHS-Net study. Journal of Food Protection, 79(9), 1588-1598.

Reale, A., Trevisan, M., \& Alvisi, G. (2017). The silent enemy: Celiac disease goes viral. Journal of Cellular Physiology 233: 2693-2694. https://doi.org/10.1002/jcp.26155

Regnerová, M., \& Hes, A. (2013). CSR a spotřebitel - celiak na trhu v ČR. Trendy v Podnikání $3,63-71$.

Řezanková, H. (2007). Analýza dat z dotazníkových šetření. Prague: Professional Publishing.

Rostami, K., Bold, J., \& Parr, A. (2017). Gluten-free diet indications, safety, quality, labels, and challenges. Nutrients 9: 846 . https://doi.org/10.3390/nu9080846

Schiefert, V. M., \& Matteucci, X. (2018). Experiences of Tourists Suffering from Food Intolerances. Journal of Gastronomy and Tourism, 3(3), 191-202.

Sverker, A., Hensing, G., \& Hallert, C. (2005). Controlled by food lived experiences of coeliac disease. Jurnal of Human Nutrition and Dietetics [online]. vol. 18. [cit. 2011-11-30]. Dostupné z: $<\mathrm{http}: / /$ onlinelibrary.wiley.com/doi//j x x/pdf $>$.

Sverker, A. (2009). I lose all these hours ...- exploring gender and consequences of dilemmas experienced in everyday life with coeliac disease. Scandinavian Journal of Caring Sciences [online]. 23, 342-352. [cit. 2011-12-03]. Dostupné z: $<$ http://onlinelibrary.wiley.com/ doi/10.1111/j.1471-6712.2008.00628.x/pdf $>$.

Švec, R., Navrátil, J., Pícha, K., \& White Baravalle Gilliam, V.L. (2012). The Perception of the Quality of Accommodation Establishments' Product. Deturope. 4(2), 4-21.

Tessmer, KA. (2003). Gluten-Free for a Healthy Life: Nutritional Advice and Recipes for those Suffering from Celiac Disease and Other Gluten-Related Disorders, 1st edn. New Page Books, Franklin Lakes, NJ.

Thomas, L., Ghiselli, R., \& Almanza, B. (2011). Congregate meal sites participants: Can they manage their diets? International Journal of Hospitality Management 30: 31-37. https://doi.org/10.1016/j.ijhm.2010.04.006

Towers, N., \& Pratten, J. (2003). Managing special dietary needs for food allergies in the hospitality industry; a survey based on the Coeliac disorder. International Journal of Hospitality Management 22, 341-351. https://doi.org/10.1016/S0278-4319(03)00066-5

Umeed, M. (2012). Travelling with allergies. Practice Nurse, 42(9), 26-30.

Zarkadas, M., Dubois, S., \& MacIsaac, K. (2013). Living with coeliac disease and a glutenfree diet: A Canadian perspective. Journal of Human Nutrition and Dietetics 26: 10-23. https://doi.org/10.1111/j.1365-277X.2012.01288.x

Zoll, F., Specht, K., \& Opitz, I. (2017). Individual choice or collective action? Exploring consumer motives for participating in alternative food networks. International Journal of Consumer Studies 42: 101-110. https://doi.org/10.1111/ijcs.12405 